\title{
Experimental Study of a Lab Scale Hybrid Fixed Bed Gasifier
}

\author{
Robert Eliraison Moshi ${ }^{1,2}$, Thomas Thomas Kivevele ${ }^{1,3}$, Yusufu Abeid Chande Jande ${ }^{1,3, \text { * }}$ \\ ${ }^{1}$ Department of Materials and Energy Sciences and Engineering, The Nelson Mandela African Institution of Science and Technology, \\ Arusha, Tanzania \\ ${ }^{2}$ Department of Automotive Engineering, Arusha Technical College, Arusha, Tanzania \\ ${ }^{3}$ African Centre of Excellence in Water Infrastructure and Sustainable Energy Futures (WISE-Futures), The Nelson Mandela African \\ Institution of Science and Technology, Arusha, Tanzania
}

\author{
Email address: \\ yusufu.jande@nm-aist.ac.tz (Y.A. C. Jande) \\ ${ }^{*}$ Corresponding author
}

\section{To cite this article:}

Robert Eliraison Moshi, Thomas Thomas Kivevele, Yusufu Abeid Chande Jande. Experimental Study of a Lab Scale Hybrid Fixed Bed Gasifier. American Journal of Applied Scientific Research. Vol. 5, No. 4, 2019, pp. 68-73. doi: 10.11648/j.ajasr.20190504.12

Received: December 21, 2019; Accepted: January 9, 2020; Published: February 4, 2020

\begin{abstract}
Thermo-chemical conversion technologies (incineration, gasification and pyrolysis) have emerged as potential technologies for municipal solid waste management (MSWM). This is happening due to the increase of the need for clean and sustainable energy as a result of fossil fuel depletion. The increase in municipal solid waste (MSW) generation as well as land scarcity for MSW disposal is another reason in raising the potential for thermal technology. Incineration has been the most common thermo-chemical technology for solid waste disposal. However, due to environmental concern, gasification technology is currently becoming more preferable since it is environmental friendly for MSW disposal as well as energy recovery. The aim of this study is to analyze the flue gases obtained from the hybrid fixed bed gasifier during gasification of MSW. The fire was initiated by wood charcoal and six kilograms of MSW was fed in the gasifier. The combustion was supported by the air supplied by electric blower. The flue gas analyzer, TESTO 327-1 was used to analyze the concentration of $\mathrm{CO}, \mathrm{CO}_{2}$ and $\mathrm{O}_{2}$. Results show that after 150 minutes of the gasification process, $\mathrm{O}_{2}$ concentration increased by $17.2 \%$ while $\mathrm{CO}$ and $\mathrm{CO}_{2}$ decreased by $0.0 \%$ and $3.77 \%$ respectively. The experimental results show that, during gasification process the $\mathrm{O}_{2}$ concentration was increasing with time while $\mathrm{CO}$ and $\mathrm{CO}_{2}$ concentration decreased.
\end{abstract}

Keywords: Municipal Solid Waste, Municipal Solid Waste Management, Gasification, Hybrid Fixed Bed Gasifier, Thermochemical

\section{Introduction}

In the developing countries municipal solid waste (MSW) generation has increased tremendously due to population growth, and changes in life style. This leads to urbanization and land scarcity in most of the urban areas, which enforce alternative methods for municipal solid waste management (MSWM). Thermochemical conversion methods such as gasification, pyrolysis, and incineration have become potential technologies for MSWM. Among the three thermochemical technologies, gasification is considered to be more effective due to its high volume and mass reduction as well as energy recovery from MSW with less environmental pollution [1-3]. This type of technology converts chemical elements contained in biomass solid fuel into syngas including hydrogen and carbon monoxide $[4,5]$. The choice of gasification technology is fueled by an increase in energy demand as well as depletion of conventional fossil fuel and therefore raise the needs for alternative and renewable energy sources including biomass wastes [6].

MSW is an available biomass that can be gasified to generate fuel gases such as carbon monoxide, hydrogen, methane and other useful gases [7,8]. These gases can be used to run gas turbines, fuel cells and gas engines for heat and power generation. Gasification reactions in the gasifier involve the integration of combustion and gasification. According to [9-11], this includes chemical reactions such as 
boudouard and $\mathrm{CO}$ oxidation as shown in Table 1 . Commonly, three types of fixed bed gasifier have been developed which are downdraft, updraft, and cross draft. In all three types, biomass is fed at the top flowing downward, their main difference being on the direction of the gasification agent as well as the direction of the produced syngas. In the downdraft gasifier, gasification agent is introduced about the center at a certain height above the throat while producer gas is tapped at the bottom. This arrangement provides clean output gases as compared to the other two types. The updraft gasifier is arranged in such a way that a gasification agent is introduced at the bottom flowing upward [12]. This produces gases with high tar and moisture content. Alternatively, gasification agent in a cross draft gasifier neither flows downward nor upward but across the gasifier. This gasifier type can handle biomass with high moisture content than the other two types. The main objective of this study is to design and develop a hybrid fixed bed gasifier (HFBG) consisting of downdraft and cross draft gasifier features.

Table 1. Combustion and Gasification reactions.

\begin{tabular}{llll}
\hline S/N & Reaction & Reaction name & $\begin{array}{l}\text { Gasifier } \\
\text { zone }\end{array}$ \\
\hline 1 & $\mathrm{C}+0.5 \mathrm{O}_{2}=\mathrm{CO}$ & Carbon partial combustion & $\begin{array}{l}\text { Combustion } \\
2\end{array}$ \\
$\mathrm{C}+\mathrm{O}_{2}=\mathrm{CO}_{2}$ & Carbon complete combustion & Combustion \\
3 & $\mathrm{C}+\mathrm{CO}_{2}=2 \mathrm{CO}$ & Boudouard & Gasification \\
4 & $\mathrm{CO}+0.5 \mathrm{O}_{2}=\mathrm{CO}_{2}$ & $\mathrm{CO}$ oxidation & Combustion \\
\hline
\end{tabular}

Researchers have carried out several gasifier designs and experimental studies on biomass gasification including wood pieces and sawdust $[4,13,14]$. However, few have worked on the design and experimental studies on a gasifier specifically for MSW gasification. Dong [15], carried out the MSW pyro-gasification experimental investigation in a fluidized bed reactor. In his study, MSW including paper, wood, plastics, and food wastes were fed separately and later on as a mixture in the reactor under nitrogen, steam, and carbon dioxide environment respectively. It was revealed that gasification reaction which used steam as gasification agent produced a high quality syngas compared to the other two. Furthermore, Gao et al [16] conducted an experimental study of MSW air-gasification using copper $\gamma$-alumina and nickel $\gamma$-alumina catalysts. It was revealed that as catalyst increased it influenced the rate of hydrogen output. However, it is well known that using catalyst implies more costs in the gasification process.

Lomasney, Michmerhuizen [17] designed and constructed a pilot plant with throatless gasifier. Performance analysis was carried out at a maximum attained temperature of $600^{\circ} \mathrm{C}$ and problems such as bridging, air leaks, ash build-up, high levels of tar production, insufficient air feed, and a failure to reach desired temperatures were encountered. The gasifier had to be redesigned with some changes in the feed hopper, ash grate, and manifold system. Chawdhury and Mahkamov [18] designed and fabricated a small downdraft gasifier JRB1 with a capacity of about 6 to $7 \mathrm{~kW}$ using stainless steel sheet and pipes. The design incorporates a conical tube of 2.5 $\mathrm{mm}$ thick placed at the top part of the gasifier to avoid bridging. Also, the design was equipped with stirrer fixed at the top cover and connected to the grate by a $15 \mathrm{~mm}$ diameter shaft. The stirrer was used to stir the glowing charcoal bed in the reduction zone and thus helps to prevent bridging. However, it was reported that the fuel feeding process was difficult due to the position of a stirrer.

Sivakumar and Ragunathan [19] designed and fabricated a $5 \mathrm{kWe}$ downdraft gasifier using empirical data. Performance analysis was carried out with different throat diameters $(60$, 90 and $120 \mathrm{~mm}$ ). Results indicated that $90 \mathrm{~mm}$ diameter had better performance efficiency than the other two. However, it was reported that carbon conversion efficiency for the small throat is always high due to the high temperature attained in the reaction zone. The reason for the $60 \mathrm{~mm}$ diameter throat not having good efficiency was due to bridging. Jayah [20] carried out the performance evaluation on the downdraft wood gasifier for evaluation of tea manufacturing in Srilanka and concluded that more investigation is needed on the effects of different throat sizes on the performance of the gasifier to determine the optimum throat size.

It has been revealed that fixed bed gasifiers face problem of feed stock flow. It is also difficult to maintain uniform operating temperatures as well as to ensure adequate gas mixing in the reaction zones. To mitigates the challenge associated with feedstock flow in the gasifier, various researchers investigated and recommended the use of throatless gasifiers [21]. Despite the fact that throatless design mitigates the biomass flow problem, it has some shortfalls such as lower combustion temperature usually below $800^{\circ} \mathrm{C}$ which results in the increase of tar production [22].

Dhaundiyal and Gupta [23] reported that throat-less downdraft gasifier can overcome bridging and channeling problems but this reduces the benefits of having throttle design whereas better mixing of gases is achieved at this region. Ojolo and Orisaleye [14], reported on their laboratory-scale biomass gasifier design that during the gasification process using palm kernel shell, bridging problems were experienced.

Therefore, it can be seen that the main outstanding challenge with downdraft throttled gasifier is bridging and channeling as reported in most of the presented studies. It was also noted that throttled downdraft gasifier produces gas with low tar. However, there is outstanding work to be done on investigating how the tar breakdown mechanism takes place in the gasifier. Moisture content is also a major factor that affects gasifier efficiency [24]. In this study, a novel MSW gasifier was designed to address moisture content problems in the wastes as well as the improvement of tar thermal cranking in downdraft gasifiers.

\section{Methods and Design Procedures}

This section present the methodology used to carry out the study. The procedure consisted of Gasifier design, fabrication of gasifier parts, random collection of MSW and performing 
experimental analysis. Dimension of gasifier components is categorized into two design parameters which are:

i. Principal design parameters including specific gasification rate and area of air nozzle.

ii. Derived parameters such as diameter of hearth, length of zones and number of nozzle [19].

According to Zafar [25], downdraft fixed bed gasifier thermal capacity ranges between $1 \mathrm{~kW}$ to $1 \mathrm{MW}$. In this study, the output of the gasifier was assumed to be $5-10 \mathrm{~kW}$. To achieve the aforementioned gasifier output the nozzle air inlet velocities and angle of inclination for the throat was considered to be in a range of $30-35 \mathrm{~m} / \mathrm{s}$ and $45^{\circ}-60^{\circ}$ respectively [26]. Design parameters such as gas residence time, specific gasification rate, area of air nozzle, hearth diameter, throat diameter, nozzle diameter, the number of nozzles, length of the combustion zone, length of reduction zone and air velocity were determined. These parameters were also calculated in the study done by Sivakumar et al, [19].

\subsection{Power Output}

Thermal output power (TOP) of the gasifier is assumed at $20 \mathrm{kWth}$ and the energy content (HHV) of MSW at Arusha is $12 \mathrm{MJ} / \mathrm{kg}$ as reported earlier by Omari et al, [27]. These two factors were used to determine the biomass consumption rate (BCR) for the gasifier which is given by equation 1 .

$$
B C R=\frac{T O P}{H H V}
$$

\subsection{Throat Diameter}

Throat diameter was determined by the use of hearth load $\left(\mathrm{B}_{\mathrm{g}}\right)$ using the expression given in equation 2 .

$$
B_{g}=2.5 B_{s}
$$

Where $B_{g}$ is the hearth load ranging between 0.1-0.9 $\mathrm{Nm}^{3}$ per $\mathrm{hcm}^{2}$ representing the ratio of the amount of producer gas to the surface area of the smallest circumference defined in $\mathrm{m}^{3} / \mathrm{cm}^{2} / \mathrm{h}$. B is the ratio of dry fuel consumed divided by the surface area of the smallest gasifier constriction. The factor of 2.5 shown in equation 2 represent the amount of producer gas in cubic meter produced from $1 \mathrm{~kg}$ of dry fuel.

Hence,

$$
\mathrm{B}_{\mathrm{s}}=\frac{6 \mathrm{~kg} / \mathrm{h}}{\mathrm{A}}
$$

Therefore, substituting equation 3 into 2 results to equation 4

$$
\frac{\mathrm{Bg}_{\mathrm{g}}}{2.5}=\frac{6}{\mathrm{~A}}
$$

Assuming that $\mathrm{B}_{\mathrm{g}}=0.3$, and substituting this value into equation 4 , the area of the throat was determined.

\subsection{Diameter of Hearth}

The relationship between throat diameter $\left(d_{t}\right)$ and hearth diameter $\left(d_{h}\right)$ is expressed in equation 5 below.

$$
\frac{d_{h}}{d_{t}}=3.5
$$

\subsection{Height of the Reactor}

As shown in Table 2, the height of the reactor was determined depending on the quantity of feedstock to be gasified in relation to its density, duration for gasification and the flow rate.

Table 2. Feedstock flow rate.

\begin{tabular}{lll}
\hline S/N & Description & Values \\
\hline 1 & Density & $314.9 \mathrm{~kg} / \mathrm{m}^{3}$ \\
2 & Duration & $4 \mathrm{hrs}$ \\
3 & Flow rate & $6 \mathrm{~kg} / \mathrm{h}$ \\
4 & Total flow & $24 \mathrm{~kg}$ \\
\hline
\end{tabular}

The volume of the reactor was calculated according to equation 6 , therefore:

$$
\text { Volume }=\frac{\text { mass }}{\text { density }}
$$

The value of reactor volume obtained in equation 6, enabled the calculations of the gasifier height.

\subsection{Reduction Zone Height}

The mathematical expression in equation 7 was used to evaluate the value of reduction zone height

$$
\frac{\mathrm{H}_{\mathrm{r}}}{\mathrm{D}_{\mathrm{t}}}=2
$$

After substituting the value of throat diameter into equation 7 , the height of the reduction zone was obtained.

\subsection{Design of the Nozzle Position}

The position of the nozzle above the smallest cross sectional area (CSA) of the throat was based on the mathematical expression shown in equation 8 , where $d_{t}$ is the throat diameter.

$$
\frac{h_{n z}}{d_{t}}=1.6
$$

\subsection{Nozzle Area}

The relationship between the areas of the nozzle to the area of throat is given as $\frac{A_{n}}{A_{t}}=0.07$. Therefore, the area occupied by the nozzle is $350 \mathrm{~mm}^{2}$. If four nozzles are used at the throat and one nozzle at the cross draft features, the cross sectional area for each nozzle would be $70 \mathrm{~mm}^{2}$, hence the nozzle diameter is $10 \mathrm{~mm}$ at an inclination angle of 10-25.

\subsection{Gasifier Fabrication and Experimental Setup}

\subsubsection{Gasifier Fabrication}

The HFBG was fabricated by using stainless steel (SS304) materials with thickness of $2 \mathrm{~mm}$ for both combustion chambers. Other parts of the gasifier were fabricated using mild steel sheets with a thickness of $2 \mathrm{~mm}$. The fuel hopper has a conical shape and was fabricated from $2 \mathrm{~mm}$ thick mild 
steel materials having top and bottom diameters of $780 \mathrm{~mm}$ and $280 \mathrm{~mm}$ respectively. The hopper height was estimated at $250 \mathrm{~mm}$ and was coned at an angle of $45^{\circ}$ so as to assist the flow of feedstock. Four air nozzles at the first combustion zone were positioned at $128 \mathrm{~mm}$ above the throat and a single air nozzle for the second combustion zone was positioned at $522.5 \mathrm{~mm}$ below the throat. Figure 1 shows the configuration of a designed gasifier.

Reaction zones consist of drying, pyrolysis, combustion, reduction, and second combustion which are located below the hopper. The gasifier consists of hopper, gasification zone, a casing for gasification zone, ash collection tray, gas outlet, air inlet pipes and gasifier housing.
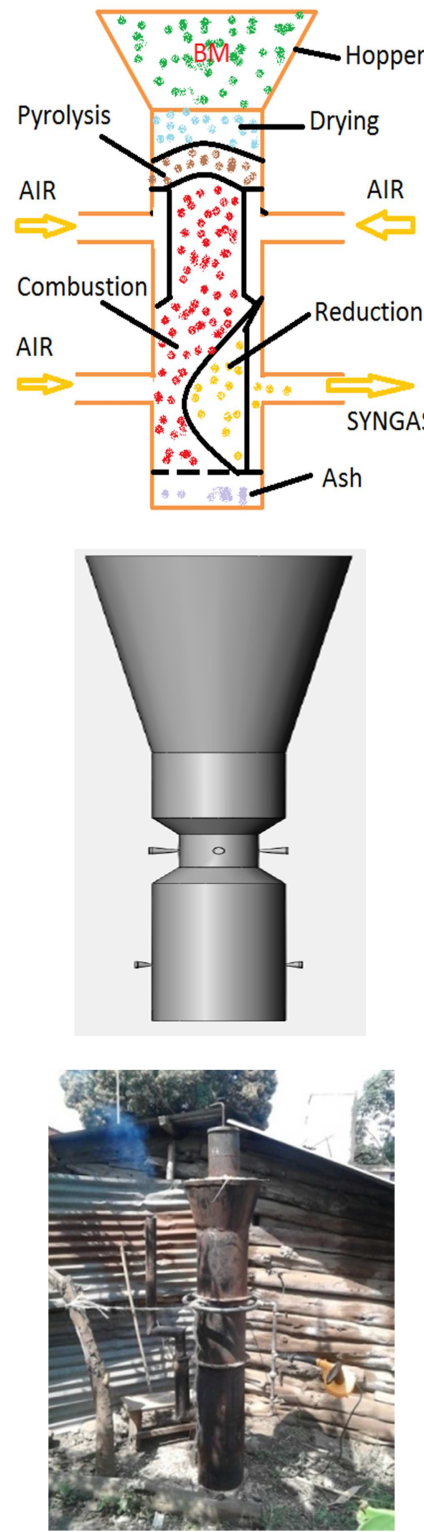

Figure 1. The gasifier main parts.

\subsubsection{Experimental Setup and Procedures}

The MSW was shredded into small particle sizes of approximately $10 \mathrm{~mm}-30 \mathrm{~mm}$ size in order to facilitate easier flow of feedstock at throat and also the heat penetration. About $6 \mathrm{~kg}$ was fed at the top of the gasifier hopper. The fire was initiated by wood charcoal placed at the fire grate. The waste flows downward into the drying section by gravitational force. The moisture content was removed by the heat generated in the first combustion zone. Dry MSW from this section flows into the pyrolysis zone thereafter to the first combustion zone. In the first combustion zone air less than stoichiometric amount was supplied by an electric blower to assist the combustion reaction. The second combustion zone is located at the bottom of the gasifier to support the combustion of the remaining char. Gasification zone is located between the two combustion zones.

Results were taken and recorded at an interval of every 30 minutes, by using the flue gas analyzer TESTO 327-1. The $\mathrm{CO}_{2}$ and $\mathrm{O}_{2}$ results obtained from the experimental study were used to evaluate values of $\mathrm{CO}$ by using Karjakin diagram shown in Figure 2.

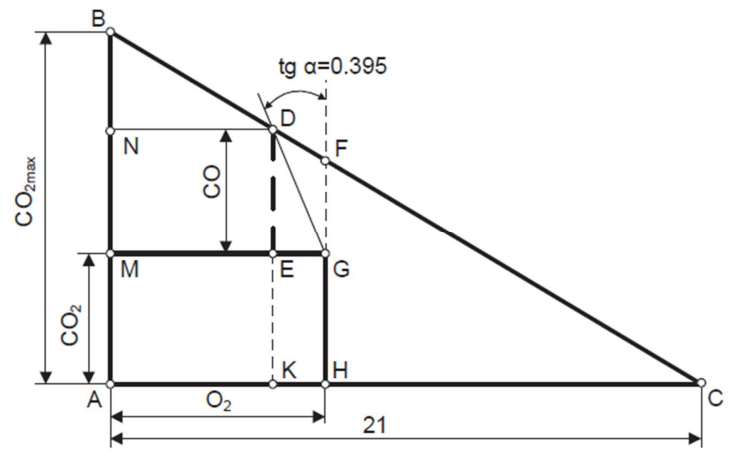

Figure 2. Karjakin diagram [28].

\section{Results and Discussion}

This section discusses the results obtained from the experimental study conducted. The procedure for the design of the gasifier involves the finding of various important parameters including throat diameter, diameters of the hearth, height of the reactor, reduction zone height, diameter and the position of nozzles respectively. Design calculations using various formulas shown were applied in obtaining different gasifier parameters presented in Table 3 .

Table 3. Results of the gasifier design.

\begin{tabular}{lll}
\hline S/N & Parameters & Results \\
\hline 1 & Throat diameter & $80 \mathrm{~mm}$ \\
2 & Throat height & $365 \mathrm{~mm}$ \\
3 & Hearth diameter & $280 \mathrm{~mm}$ \\
4 & Height of the reactor & $1250 \mathrm{~mm}$ \\
5 & Height of reduction zone & $160 \mathrm{~mm}$ \\
6 & Hopper inner diameter & $280 \mathrm{~mm}$ \\
7 & Hopper outer diameter & $780 \mathrm{~mm}$ \\
8 & Hopper height & $250 \mathrm{~mm}$ \\
9 & Nozzle diameter & $10 \mathrm{~mm}$ \\
10 & Position of the nozzle above the throat & $128 \mathrm{~mm}$ \\
\hline
\end{tabular}

The HFBG was designed based on a thermal output power of about $20 \mathrm{~kW}$. At the initial stage, the thermocouple type K was used to measure the temperature of the gasifier which was found to be $100^{\circ} \mathrm{C}$ to $300^{\circ} \mathrm{C}$. At this stage the quality of 
the gas was poor because the temperature in the gasifier was still low. This is the cold start phase which took about 30 minutes from when the material was fed into the gasifier. At this phase the composition of flue gases was not recorded.

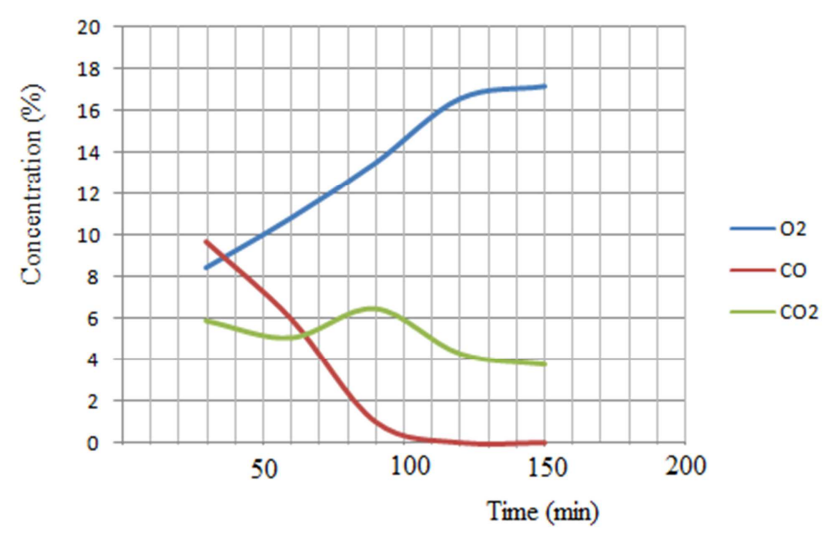

Figure 3. Concentration of $\mathrm{O}_{2}, \mathrm{CO}$ and $\mathrm{CO}_{2}$ with time.

After the elapse of the initial 30 minutes, the result recorded shows that $\mathrm{O}_{2}$ concentration was increasing with time while $\mathrm{CO}$ and $\mathrm{CO}_{2}$ were decreasing as shown in Figure 3. This was evidence that the developed model was viable for MSW gasification.

\section{Conclusion}

The study presents the result obtained from the HFBG which was designed to deliver $20 \mathrm{~kW}$ thermal power, particularly for MSW gasification. During laboratory analysis results indicated that with time there was an increase in oxygen while carbon dioxide, and carbon monoxide, decreased. During analysis, data were recorded in the interval of every 30 minutes for a period of 2.5 hours. Results show that after 150 minutes of the gasification process, $\mathrm{O}_{2}$ concentration increased by $17.2 \%$ while $\mathrm{CO}$ and $\mathrm{CO}_{2}$ decreased by $0.0 \%$ and $3.77 \%$ respectively. Therefore, this novel gasifier is viable for the gasification of MSW.

\section{Recommendations}

The analysis of the study was carried out by investigating the trends of $\mathrm{CO}, \mathrm{CO}_{2}$ and $\mathrm{O}_{2}$ produced by the hybrid fixed bed gasifier. The analysis mostly based on the percent concentration of $\mathrm{CO}, \mathrm{CO}_{2}$ and $\mathrm{O}_{2}$ produced by the gasifier incorporating downdraft and cross draft features. It was revealed that the gasification of MSW using the aforementioned gasifier was feasible. However, further studies on the gases output such as methane, hydrogen, sulfur dioxides and nitrogen oxides should be carried out.

\section{Acknowledgements}

I delightedly extend my earnest gratitude to all those who provided viable contributions that enabled the smooth execution of this study. Their contributions are invaluable, reminiscent and hence, unforgettable. I grateful acknowledge to my employer, Arusha Technical College for granting me time to undertake this study. However, apart from my employer, I am obliged to also acknowledge the regional manager for the small industries development organization (SIDO) at Arusha Tanzania, for allowing me to access their equipment in fabricating the gasifier.

\section{Conflict of Interest}

The authors declare that there is no conflict of interest concerning this research work, and from the best knowledge of authors, this work is original.

\section{References}

[1] Ramzan, N., Ashraf, A., Naveed, S. and Malik, A. (2011). Simulation of hybrid biomass gasification using Aspen plus: A comparative performance analysis for food, municipal solid and poultry waste. Biomass and Bioenergy, 35 (9): p. 39623969 .

[2] Begum, S., Rasul, M. G., Akbar D. And Cork D. (2013). An experimental and numerical investigation of fluidized bed gasification of solid waste. Energies, 7 (1): p. 43-61.

[3] Chen, C., Jin, Y., Yan, J. and Chi, Y. (2013). Simulation of municipal solid waste gasification in two different types of fixed bed reactors. Fuel, 103: p. 58-63.

[4] Ingle, N. A. and Lakade, S. S. (2016). Design and development of downdraft gasifier to generate producer gas. Energy Procedia, 90: p. 423-431.

[5] Moharkar, S. P. and Padole, P. D. (2012). Design and development of downdraft gasifier for rural area. International Conference on Emerging Frontiers in Technology for Rural Area (EFITRA) Proceedings published in International Journal of Computer Applications (IJCA).

[6] Thakare, S. and Nandi, S. (2016). Study on potential of gasification technology for municipal solid waste (MSW) in Punecity. Energy Procedia, 90: p. 509-517.

[7] Basu, P. (2006). Combustion and gasification in fluidized beds. Taylor and Francis. CRC press.

[8] Zainal, Z. A., Ali, R., Lean, C. H and Seetharamu, K. N. (2001). Prediction of performance of a downdraft gasifier using equilibrium modeling for different biomass materials. Energy conversion and management, 42 (12): p. 1499-1515.

[9] Han, J., Liang, Y., Hu, J., Qin, L., Street, J., Lu, Yand Yu, F. (2017). Modeling downdraft biomass gasification process by restricting chemical reaction equilibrium with Aspen Plus. Energy conversion and management, 153: p. 641-648.

[10] Chen, C., Jin, Y., Yan, J. and Chi, Y. (2010). Simulation of municipal solid waste gasification for syngas production in fixed bedreactors. Journal of Zhejiang University-Science A, 11 (8): p. 619-628.

[11] Meng, X. (2012). Biomass gasification: the understanding of sulfur, tar, and char reaction in fluidized bed gasifiers. MSc thesis submited in the process and energy Faculty, Delft University of Technology. 
[12] Kramreiter, R., Url, M., Kotik, J. and Hofbauer, H. (2008). Experimental investigation of a $125 \mathrm{~kW}$ twin-fire fixed bed gasification pilot plant and comparison to the results of a 2MW combined heat and power plant (CHP). Fuel Processing Technology, 89 (1): p. 90-102.

[13] Narendrabhai, S. S., Shaikh, M. H. and Sachin, P. (2018). Design, developmentand experimental studies of downdraft gasifier. International Journal of Advance Research, Ideas and Innovations in Technology, 4 (3):p. 7.

[14] Ojolo, S. J. and Orisaleye J. I. (2010). Design and development of a laboratory scale biomass gasifier. Journal of Energy and Power Engineering, 4 (8).

[15] Dong, J. (2016). MSWs gasification with emphasison energy, environment and life cycle assessment. Ecole des Minesd'Albi-Carmaux Zhejiang University.

[16] Gao, W., Farahani M. R., Rezael, M., Hosamani, S. M., Jamil, M. K., Imran, M. and Baig, A. Q. (2017). Experimental study of steam-gasification of municipal solid wastes (MSW) using $\mathrm{Ni}-\mathrm{Cu} / \gamma-\mathrm{Al}_{2} \mathrm{O}_{3}$ nanocatalysts. Energy Sources, Part A: Recovery, Utilization, and Environmental Effects, 39 (7): p. 693-697.

[17] Lomasney, M., Michmerhuzen, N., Myton, N., and Sager, E. (2014). BIOburners. Final Design Report. Calvin College Engineering Department.

[18] Chawdhury, M. A. and Mahkamov, K. (2011). Development of a small downdraft biomass gasifier for developing countries. Journal of scientific research, 3 (1): p. 51-51.

[19] Sivakumar, S., Ragunathan, S. and Elango, N. (2014). Design and optimization analysis of $5 \mathrm{kWe}$ Downdraft Gasifier. Journal of Chemical and Pharmaceutical Sciences, 4: p. 141143.
[20] Jayah, T. H., (2002). Evaluation of a downdraft wood gasifier for tea manufacturing in SriLanka. Melbourne University: Victoria, Australia.

[21] Bhavanam, A and Sastry, R. (2013). Modelling of solid waste gasification process for synthesis gas production. Journal of Scientific and Industrial Research, Vol 72.

[22] Zwart, R., Vander Heijden, S., Emmen, R., DallBentzen, J., ahrenjeldt, J., Stoholm, P. and Krogh, J. (2010). Tar removal from low-temperature gasifiers. Petten: Energy Research Centre of the Netherlands (ECN). ECN-E-10-008.

[23] Dhaundiyal, A. and Gupta, V. K. (2014). The analysis of pine needles as a substrate for gasification. Hydro Nepal: Journal of Water, Energy and Environment, 15: p. 73-81.

[24] Plis, P. and Wilk, R. K. (2011). Theoretical and experimental investigation of biomass gasification process in a fixed bed gasifier. Energy, 36 (6): p. 3838-3845.

[25] Zafar, S. (2009). Gasification of Municipal Solid Waste "Earthtoys Magazine "EESI.

[26] Montes, F. D. d., (1986). Wood gas as engine fuel. FAO Forest paper, 72 .

[27] Omari, A., Said, M., Njau, K., John, G., and Mtui, P. (2014). Energy recovery routes from Municipal Solid Waste, A case study of Arusha-Tanzania. Journal of Energy Technologies and Policy, 4 (5): p. 1-7.

[28] Suzdalenko, V., M. Gedrovics, and V. Vitolins, (2014). Experimental pilot device for thermal analysis of biomass cofiring. Agronomy Research, 12 (2): p. 611-622. 